\title{
ウシ歯胚の象牙芽細胞層およびエナメル芽細胞層における 乳酸脱水素酵素含有基質小胞様小胞に関する研究
}

\author{
北村 知 昭 \\ 九州歯科大学大学院歯学研究科歯科保存学第 1 専攻 (指導 : 寺下正道教授) \\ 九州歯科大学生化学講座 (指導 : 野口知雄教授) \\ 日本学術振與会特別研究員 (受人指導者：寺下正道教授)
}

平成 4 年 10 月 26 日受理

Studies on the Lactate Dehydrogenase-containing Vesicles of the Odontoblast Layer and the Ameloblast Layer of Bovine Tooth Germs Chiaki Kitamura

Department of Operative Dentistry (Director : Prof. Masamichi Terashita) Department of Biochemistry (Director: Prof. Tomoo Noguchi)

Fellowships of the Japan Society for the Promotion of Science for Japanese Junior Scientists (Director of Recipient: Prof. Masamichi Terashita) Kyushu Dental College, Kitakyushu, Japan

Matrix vesicles, membrane invested vesicles, are generally accepted to initiate mineralization in the extracellular matrix of calcifying tissues except enamel. Matrix vesicles contain high alkaline phosphatase activity and related phosphatase activities associated with the plasma membrane; this may be because matrix vesicles may be formed by budding from the plasma membrane of calcifying cells.

Recently, lactate dehydrogenase ( $\mathrm{LDH}$ )-containing vesicles were found in the epiphyseal growth cartilage [Hosokawa et al. (1988) J. Biol. Chem. 263, 10045-10047] and the resting cartilage [Ohashi-Takeuchi et al. (1990) Biochem. J. 266, 309-312], and in the calvaria of mice [Naito (1992) J. Kyushu Dent. Soc. 46, 345-354]. However, it is unknown what true function of $\mathrm{LDH}$-containing vesicles is and there is no report on the presence of $\mathrm{LDH}$-containing vesicles in calcification sites of developmental tooth germs.

In the present study, LDH-containing vesicles were found to be present in odontoblast layer and ameloblast layer of bovine tooth germs, as follows.

1. The extracellular matrix vesicle fraction was prepared from odontoblast layer of bovine tooth germs. Only in the presence of detergents, LDH activity was detected in the extracellular matrix vesicle fraction, showing that $\mathrm{LDH}$ is located in the vesicles.

2. The extracellular matrix vesicle fraction of bovine odontoblast layer was subjected to sucrose density gradient centrifugation. LDH activity was detected in the presence of Triton $\mathrm{X}-100$ but not in the absence of Triton $\mathrm{X}-100$. The sedimentation profiles of $\mathrm{LDH}$ in the 
presence of Triton X-100 were different from that of alkaline phosphatase, showing that LDH -containing vesicles were different from matrix vesicles.

3 . Odontoblast fraction from bovine tooth germs was homogenized with isotonic solution and then subjected to sucrose density gradient centrifugation. LDH activity was recovered only in the soluble top fraction, but not in sediment, showing that LDH in the vesicles is not simply encapsulated by vesicles from the plasma membranes or membranes of intracellular organelles.

4. Electrophoretic profiles of $\mathrm{LDH}$ isoenzymes from the extracellular matrix vesicle fraction of bovine odontoblast layer were similar to those of cytosolic LDH of bovine odontoblast, suggesting that the presence of a mechanism for the specific uptake of cytosolic lactate dehydrogenase into vesicles.

5. Furthermore, LDH-containing vesicles were found in the ameloblast layer of bovine enamel organ. The existence of $\mathrm{LDH}$-containing vesicles in bovine ameloblast layer, where calcification is not initiated by matrix vesicles, suggests the possibility that LDH-containing vesicles have a specific role different from matrix vesicles.

Key words : Matrix vesicle/Odontoblast/Ameloblast/Lactate dehydrogenase-containing vesicles/Lactate dehydrogenase

\section{緒言}

基質小胞は 1967 年に Anderson"), Bonucci らによ り骨端軟骨の細胞外基質中に初めて発見された膜性の小 胞様器官である. その後の形態学的研究により, 基質小 胞は軟骨内骨化部位だけでなく, 膜性化骨部位年 ${ }^{3.4)}$ や象牙 質の石灰化開始部位 ${ }^{5}$ にも発見された。 1970 年 Ali ら により基質小胞が単離されてから, 生化学的研究も可能 になった。その結果，この小胞には，細胞形質膜由来之 思わ机るいくかか膜酵素, 特に高い Alkaline phosphatase（以後 ALP と略称）活性が検出されることや6), 小胞膜の脂質構成が細胞形質膜と類似していること7が 明らかになった。これらの報告から，現在，基質小胞は 細胞加発芽により形成されると考えられている。 しか し，いまだに形態学的研究が主流であり，基質小胞の機 能, 形成機構などについては不明な点が多い。

最近, Hosokawa ら $(1988)^{8)}$, Takeuchi ら (1990 )$^{92}$ はラット肋軟骨骨端部の成長層には, ALP と乳酸脱 水素酵素 (Lactate dehydrogenase; 以後 LDH と略 称）の両活性を含有する基質小胞が存在するのに対し， 静止層には ALP を含まず LDH のみを含む基質小胞様 小胞が存在することを明らかにした。また，内藤ら (1991) ${ }^{10)}$ はラット頭蓋骨の膜性化骨部位の初期石灰化
開始時に LDH を含む基質小胞様小胞が存在することを 明らかにした。しかしながら，これらの LDH を含む小 胞の生理的意義は不明である.

本研究では，基質小胞性石灰化を行うウシ歯胚象牙芽 細胞層に，LDH を含む基質小胞様小胞が存在すること を明らかにすると共に，基質小胞の関与しない上皮性石 灰化を行うウシ歯胚エナメル芽細胞層における LDH を 含む小胞の存在について検討を行った.

\section{実験材料及び方法}

I. 材料

A．ウシ歯胚象牙芽細胞層およびエナメル芽細胞層の 調製法

1．象牙芽細胞層の調製

生後 $1-2$ 年のウシ下顎骨より歯胚を摘出し歯乳頭を 除去した後，スパーテルを用いて象牙質表面を静かに蛍 き取ることにより象牙芽細胞層及び象牙前質を採取し た。

2. エナメル芽細胞層の調製

摘出したウシ歯肧表層からエナメル器を剝離した。剝 離したエナメル器内表面をメスで静かに播き取ることに よりエナメル芽細胞層を採取した。

B. 試薬 
Sodium pyruvate, $p$-nitrophenylphosphate, 細胞 分散用コラゲナーゼ (和光純薬工業), penicillin-streptomycin 混合液 (M. A. Bioproducts, U. S. A.), digitonin (Merk, U. S. A.), Triton-X 100 (半井化

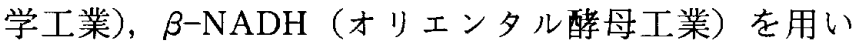
た。その他の試楽は全て市販の特級を用いた。

II. 方法

A. 酵素活性の測定法

LDH 活性は $0.1 \mathrm{M}$ pyruvate と $5 \mathrm{mM} \mathrm{NADH}$ を基質 とし， $0.25 \mathrm{M}$ sucrose を含む $0.1 \mathrm{M}$ リン酸カリ緩衝液 （pH 7.4）中で $37^{\circ} \mathrm{C}$, 一定時間反応後, $\mathrm{NADH} の 340$ $\mathrm{nm}$ における吸光度の減少から測定した"1).

ALP 活性は $0.1 \mathrm{M}$ p-nitrophenylphosphate を基質 とし, $1 \mathrm{mM} \mathrm{MgCl} 2,0.1 \mathrm{mM} . \mathrm{ZnCl}_{2}$ の存在下で $0.25 \mathrm{M}$ sucrose を含む $0.1 \mathrm{M}$ glycin- $\mathrm{NaOH}$ 緩衝液（pH 10.5） 中で $37^{\circ} \mathrm{C}$, 一定時間反応後, $1 \mathrm{~N} \mathrm{NaOH} 0.2 \mathrm{ml}$ で反応 を止め, p-nitrophenol の $405 \mathrm{~nm}$ に求ける吸光度の増 加から測定した ${ }^{122}$.

Aldolase (D-fructose-1,6-bisphosphate D-glyceraldehyde 3-phosphate-lyase, E. C. 4.1.2.13) 活性は，D-fructose- 1,6-bisphosphate を基質とし一 定時間反応後, 生成する D-glyceraldehyde 3-phosphate $と$ dihydroxyacetone phosphate glyceraldehyde-3-phosphate dehydrogenase $と$ glycerol-3phosphate dehydrogenase $の$ 存在下で NADH $の 340$ $\mathrm{nm}$ における吸光度の減少から測定した ${ }^{13}$.

Aspartate : 2-oxoglutarate aminotransferase (E. C. 2.6.1.1.) 活性は L-aspartate と 2-oxoglutaric acid を基質とし一定時間反応後, 生成する oxaloacetic acid を malate dehydrogenase $亡 \mathrm{LDH}$ の存在下で $\mathrm{NADH}$ の $340 \mathrm{~nm}$ に打ける吸光度の減少から測定し $た^{(14)}$.

Alanine : 2-oxoglutarate aminotransferase (E. C. 2. 6. 1.2.) は, L-alanine と2-oxoglutaric acid を基質とし一定時間反応後，生成する pyruvate を $\mathrm{LDH}$ の存在下で NADH の $340 \mathrm{~nm}$ における吸光度 の減少から測定した ${ }^{15}$.

B． 細胞外基質小胞画分㧍よび細胞画分の調製

ウシ歯胚から調製した象牙芽細胞層およびエナメル芽 細胞層の湿重量をそれぞれ測定した後, Ali ら $(1970)^{6)}$ の方法に従い，10 倍の collagenase 溶液 (1,000 units collagenase/ml, $1.5 \mathrm{mM} \mathrm{MgCl}, 0.25 \mathrm{M}$ sucrose, 1,000 units penicillin/ml, $1 \mathrm{mg}$ streptomycin/mlを含 む $25 \mathrm{mM}$ Tris- $\mathrm{HCl}$ 緩衝液 $(\mathrm{pH} \mathrm{7.5)})$ を加え, $37^{\circ} \mathrm{C}$ で
2 時間, 振盪機で振晹しながらコラゲナーゼ処理を行っ た。 続いて処理液をナイロン布でろ過し，Wuthier ら (1978) ${ }^{16)}$ の方法に従い， $0-4{ }^{\circ} \mathrm{C}$ でろ液を分画遠心し た（Fig. 1)．コラゲナーゼ処理溶液を $1,000 \times \mathrm{g}$ で 15 分間遠心し，沈殿を細胞画分（象牙芽細胞画分，エナメ ル芽細胞画分）とした．上清を $20,000 \times \mathrm{g}$ で 20 分間遠 心後，さらにその上清を $100,000 \times \mathrm{g}$ で 60 分間遠心し 得られた沈殿を細胞外基質小胞画分とした．各組織より 得られた細胞外基質小胞画分及び細胞画分は $0.25 \mathrm{M}$ sucrose を含む $25 \mathrm{mM}$ Tris- $\mathrm{HCl}$ 緩衝液（pH 7.5）に䯚 濁し，以下の実験に用いた。

C. 細胞外基質小胞画分の LDH の界面活性剂（digitonin）による可溶化

$0.25 \mathrm{M}$ sucrose 溶液に $1.2 \%$ digitonin を加え, 加熱 溶解した後， $2{ }^{\circ} \mathrm{C}$ に冷却した。この溶液を段階的に希 釈しこれに細胞外基質小胞画分を加え擋拌後，15 分間

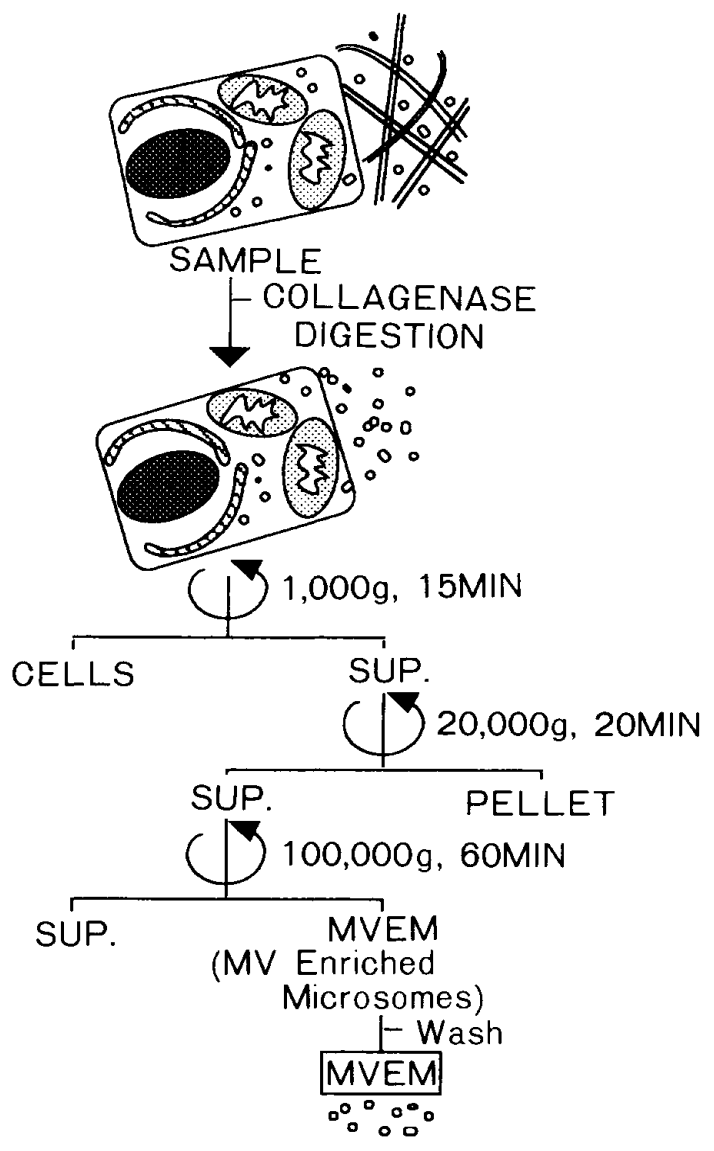

Fig. 1 Flow diagram for differential centrifugation of the extracellular matrix vesicle fraction and cell fraction from odontoblast layer and ameloblast layer of bovine tooth germs. MV, matrix vesicles. 
静置した. $100,000 \times \mathrm{g}$ で 30 分間遠心し，可溶化した上 清の LDH 活性を測定した。

D. 細胞外基質小胞画分の精製

ウシ歯胚象牙芽細胞層およびエナメル芽細胞層から分 画遠心により調製した細胞外基質小胞画分（各 $0.4 \mathrm{ml}$ )

を， $4 \mathrm{ml}$ の直線的蔗糖密度勾配 (20-54\% sucrose (w/ w) $/ 25 \mathrm{mM}$ Tris- $\mathrm{HCl}(\mathrm{pH} 7.5))$ に重層し，それぞれ バーチカルローター（RPV-50 T) を用いて 132,000× $\mathrm{g}$ で 70 分間遠心した ${ }^{(7)}$. 遠心後, 各々の遠心管の底か ら $0.3 \mathrm{ml}$ ずつ分画し，ただちに酵素活性（ALP と $\mathrm{LDH}$ ）測定して基質小胞画分を集めた．以上の操作 は, 全て 0- $4{ }^{\circ} \mathrm{C}$ で行った。

E. 細胞内オルガネラの分離

象牙芽細胞画分拈よびエナメル芽細胞画分をそれぞ れ，マイクロホモジナイザー（Physicotron，日音医理 科機械製作所）を用い，氷冷下にて目盛り 5 で 15 秒間 ホモジナイズし，形質膜を選択的に破壊した，得られた 細胞ホモジネイトを $300 \times \mathrm{g}$ で 5 分間遠心し，核之未破 壊の細胞を除き，上清を上記と同様にして $4 \mathrm{ml}$ の直線的 蔗糖密度勾配に重層し，遠心分画後，ただちに酵素活性 を測定した。 以上の操作は，全て $0-4{ }^{\circ} \mathrm{C} て ゙$ 行った。

F． 細胞からのシトゾールの調製

形質膜を選択的に破壊した上記の細胞ホモジネイト を, $100,000 \times \mathrm{g}$ で 60 分間遠心し, 得られた上清をシト ゾール画分とした。

G. 人工的小胞を含む基質小胞画分の調製

分画遠心により得られた上記の細胞画分（湿重量 1 g) $0.25 \mathrm{M}$ sucrose を含む $25 \mathrm{mM}$ Tris- $\mathrm{HCl}$ 緩衝液 （pH 7.5）に懸濁し，マイクロホモジナイザー（Physicotron，日音医理科機械製作所）を用いて 30 秒間ホモ ジナイズすることにより細胞形質膜を選択的に破壊し た.さらにハンディマイクロソニック（トミー精工社） を用いて目盛り 5 で $0{ }^{\circ} \mathrm{C}, 20$ 秒間超音波処理を行い, 細胞膜及び細胞内膜成分を破壊した後，分画遠心により 基質小胞画分を調製した。 この画分には形質膜やオルガ ネラ膜から人工的に形成された小胞が分画される.

H. 電気泳動による LDH の検出

1. ポリアクリルアミドゲル電気泳動

Fritz ら (1970 ${ }^{18)}$ の方法に従った. 分離用ゲルとし て $5 \%$ polyacrylamide gel を, 泳動用緩衝液として 50 $\mathrm{mM}$ glycine- $\mathrm{NaOH}(\mathrm{pH} 10.0)$ を用い, $4{ }^{\circ} \mathrm{C}$ で 1 時 間，1カラムあたり $5 \mathrm{mAで}$ 電気泳動を行った。

2. 活性染色

活性染色は Nitisewojo ら（1976） ${ }^{19)}$ の方法で行った.
泳動後, $0.1 \mathrm{M}$ Tris- $\mathrm{HCl}$ 緩衝液（pH 8.0）中で pyruvate, NAD と反応させた後, phenazine methosulphate を基質として nitrotetrazolium と反応させ, 生じた formazan の紫色の発色で LDH 活性の易動位置を確認 した.

I 。ウシ歯胚エナメル芽細胞層の光顕的観察

生後 1-2 年のウシ下顎骨より取り出した霜胚の表面 に存在するエナメル器を実体顕微鏡下でピンセットを用 いて雬胚より㔀離した。㔀離したエナメル器は，ただち に $10 \%$ 中性 formalin 中で 24 時間固定した。 固定後上 昇エ夕ノール系列にて脱水し，パラフィンで包埋した。 続いて，厚さ $5 \mu \mathrm{m}$ の連続切片を作成し，へマトキシリ ン及びェオジンで染色し，光顕的観察に供した。

\section{結果}

I ，ウシ歯胚象牙芽細胞層における LDH を含む小胞

A． LDH を含む小胞の同定

ウシ歯胚象牙芽細胞層から調製した細胞外基質小胞画 分は，界面活性剂である $0.2 \%$ Triton X-100あるいは $1.2 \%$ digitonin の非存在下では LDH 活性を示さなかっ た。しかし，これらの界面活性剤を添加すると LDH 活 性が出現した．象牙芽細胞層から調製した細胞外基質小 胞画分の digitonin による LDH 活性の可溶化パターン を Fig. 2 に示す. digitonin 量の増加に伴い可溶化が進 行し， digitonin 濃度 0.25\%（v/v）で，可溶化した LDH 活性は最大値に達した，以上の結果は LDH を含

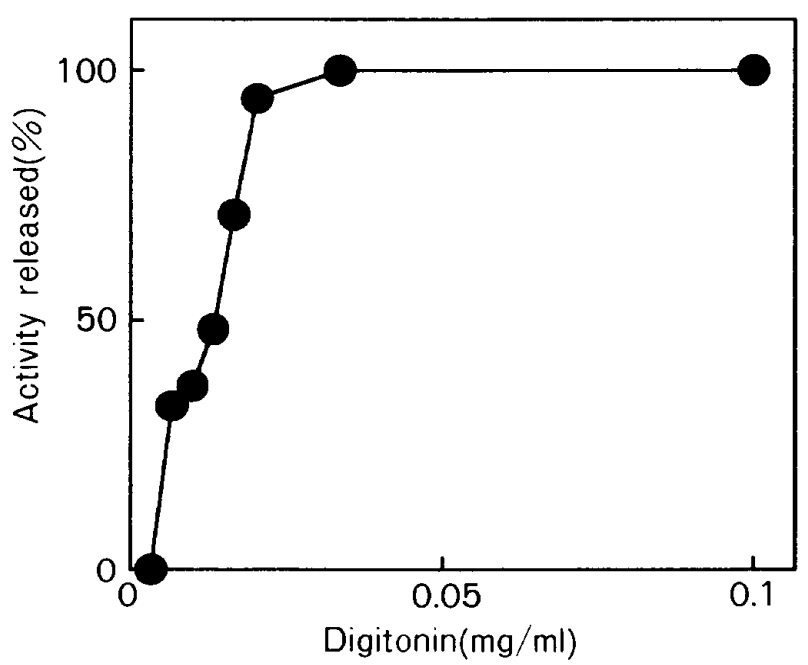

Fig. 2 Solubilization profile of lactate dehydrogenase from the extracellular matrix vesicle fraction from odontoblast layer of bovine tooth germs. 
む小胞がウシ歯肧象牙芽細胞層の細胞外基質小胞画分に 存在し, $\mathrm{LDH}$ 活性は小胞のマトリックスに存在するこ と，また LDH の基質の 1 つである $\mathrm{NADH}$ がこの小胞 膜を通過しないことを示している.

B. LDH を含む小胞の由来

象牙芽細胞ホモジネートの蔗糖密度勾配遠心分画像を Fig. 3 に示す. 界面活性剂である $0.2 \%$ Triton X-100の 存在の有無に関わらず $\mathrm{LDH}$ 活性は可溶性画分にのみ検 出され, 沈降しなかった。 以上の結果は LDH がウシ歯 肧象牙芽細胞層のシトゾールにのみ存在していることを 示している. またこのことは細胞外基質小胞画分の $\mathrm{LDH}$ 活性は細胞形質膜や細胞内オルガネラ膜に由来す るあのではないことを示している。

また象牙芽細胞画分から超音波処理により基質小胞画 分を調製し LDH 活性を測定したところ, 界面活性剂で ある $0.2 \%$ Triton X-100の存在下で象牙芽細胞ホモジ ネートの LDH 活性の約 $13 \%$ の LDH 活性が検出され た. しかし Triton X-100の非存在下でもほぼ同じ活性 が検出された。このことは人工的に作られた小胞では, $\mathrm{LDH}$ は小胞膜外表面に人工的に付着しており，小胞の マトリックスには存在していないことを示している

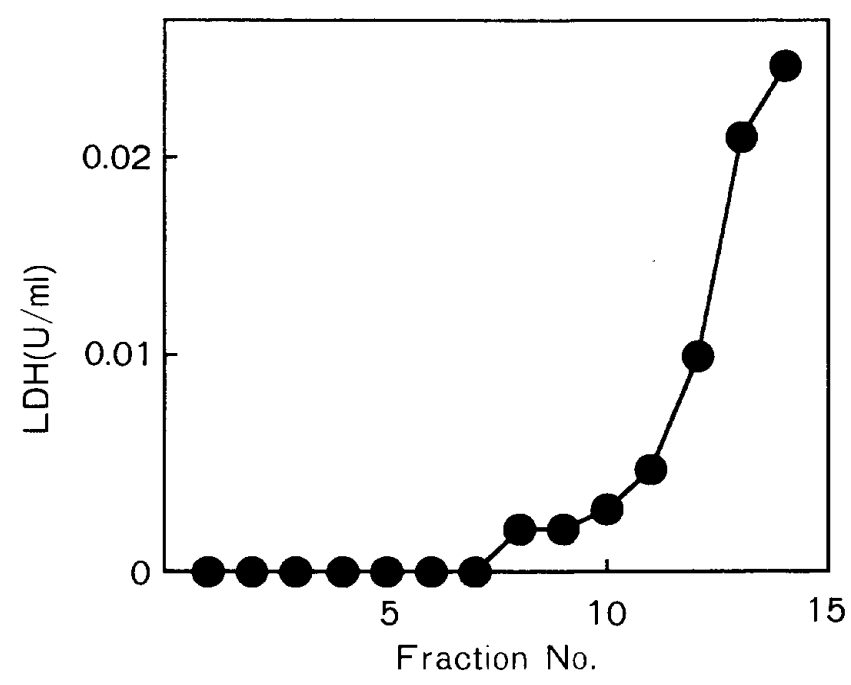

Fig. 3 Sucrose density gradient centrifugation of odontoblast homogenate. The odontoblast fraction prepared from bovine tooth germs was homogenized with 1.0 $\mathrm{ml}$ of $0.25 \mathrm{M}$ sucrose/ $25 \mathrm{mM}$ Tris- $\mathrm{HCl}$ buffer, $\mathrm{pH} 7.5$, and subjected to sucrose density gradient centrifugation. LDH activity (O) was determined in the presence of Triton $\mathrm{X}-100$. LDH, lactate dehydrogenase.

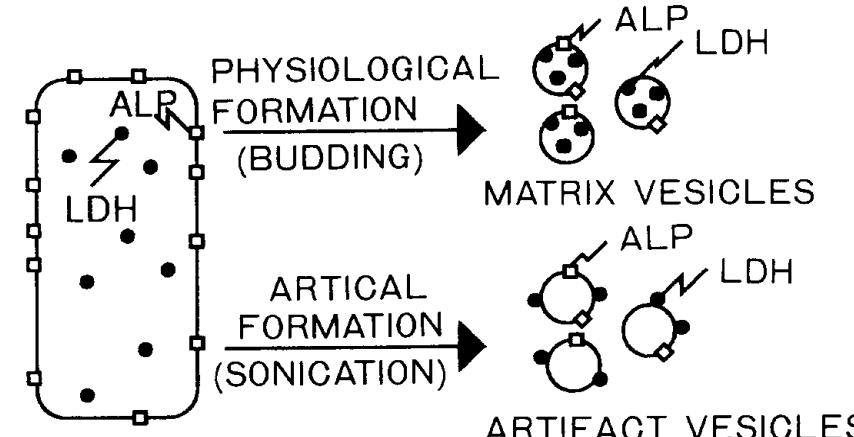

CHONDROCYTE OF GROWTH CARTILAGE

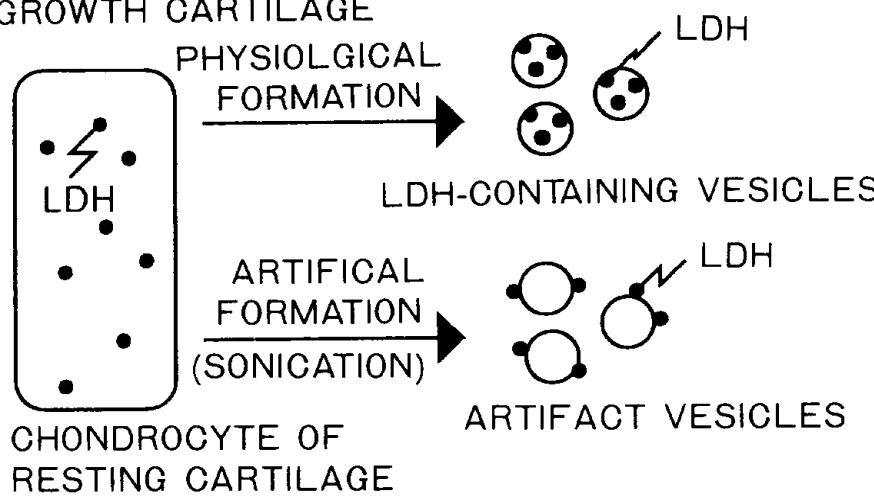

Fig. 4 The shema for the formation of matrix vesicles, LDH-containing vesicles and artifical vesicles. ALP, alkaline phosphatase; LDH, lactate dehydrogenase.

(Fig. 4).

C. 小胞の LDH アイソエンザイムパターン

ウシ歯胚象牙芽細胞層から調製した細胞外基質小胞画 分の抽出液と, 象牙芽細胞のシトゾール画分のポリアク リルアミドゲルによる電気泳動パターンを Fig. 5 に示 している. 細胞外基質小胞画分の $\mathrm{LDH}$ と象牙芽細胞シ トゾールの LDH の 5 個のアイソェンザイムパ夕ーンは 非常に類似していた。

D． LDH を含む小胞の蔗糖密度勾配遠心法による精 製

ウシ歯胚象牙芽細胞層から調製した細胞外基質小胞画 分を蔗糖密度勾配遠心分画により精製した（Fig. 6). 蔗糖密度勾配遠心分画において, 基質小胞のマーカーで ある ALP 活性は $0.2 \%$ Triton X-100の存在の有無に関 わらず同一の沈降パターンを示した。 このことはALP 活性部位が基質小胞の外表面に分布していることを示し ている。 それに対し， LDH 活性は，0.2\% Triton X100の非存在下では活性は全く検出されなかった。 とこ ろが，界面活性剂を添加すると新たに活性が出現した。 この界面活性剂存在下での LDH 活性の沈降パターンは 


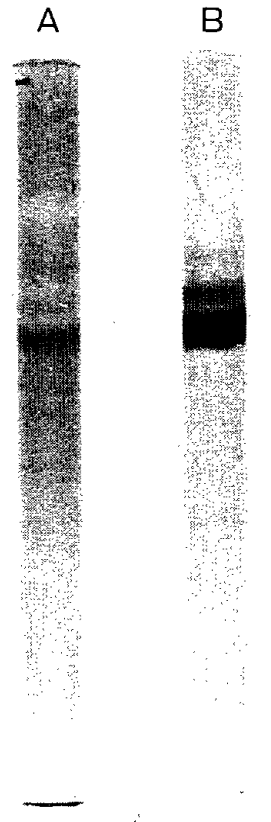

Fig. 5 Polyacrylamide gel electrophoresis of lactate dehydrogenase-containing vesicles and cytosolic lactate dehydrogenase isoenzymes. The cytosolic fractions of odontoblasts and $\mathrm{LDH}-$ containing vesicles were prepared from bovine tooth germs. LDH-containing vesicles were solubilized with $0.2 \%$ Triton $\mathrm{X}-100$ and centrifuged at $100,000 \mathrm{~g}$ for $60 \mathrm{~min}$. $\mathrm{LDH}$ -containing vesicles and the cytosolic fraction of odontoblasts were separately subjected to polyacrylamide gel electrophoresis as described in the text. A, LDH-containing vesicles; $\mathrm{B}$, cytosol of odontoblasts. LDH, lactate dehydrogenase.

ALP 活性の沈降パターンとは異なっていた，以上の結 果は, ウシ蒾胚象牙芽細胞層の細胞外基質小胞画分には 基質小胞とは異なる LDH を含む小胞が存在することを 示している.

また象牙芽細胞シトゾールに存在する他の酵素（aspartate : 2-oxoglutarate aminotransferase, alanine: 2-oxoglutarate aminotransferase, aldolase) は LDH を含む小胞中には検出されなかった.

II. ウシ歯胚エナメル芽細胞層に招ける $\mathbf{L D H}$ を含む 小胞の同定

\section{A. 光顕的観察}

ウシ歯胚から調製したエナメル器は歯胚のエナメル質 表面から完全に剝離されていた（Fig. 7)，剝離された

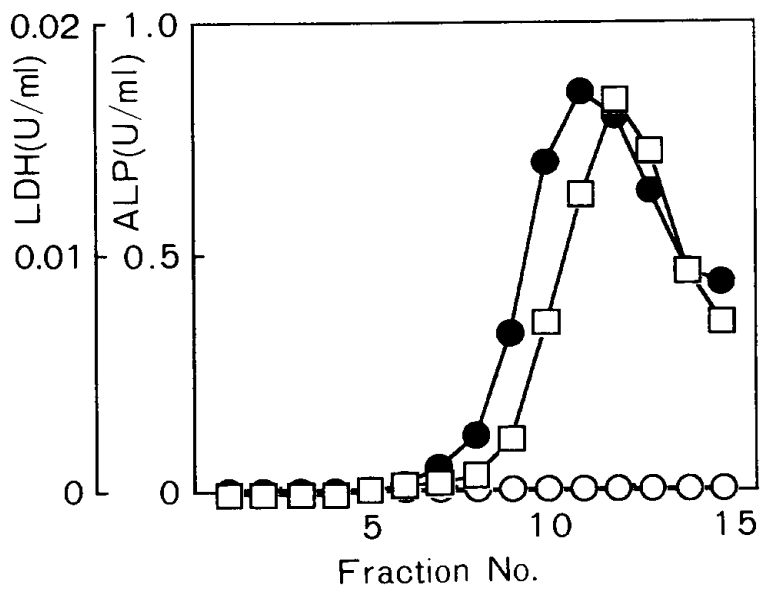

Fig. 6 Sucrose density gradient centrifugation of the extracellular matrix vesicle fraction from dentin of bovine tooth germs. Details of the procedures are described in the text. LDH activity was determined in the absence $(O)$ and the presence (O) of Triton X-100, and ALP activity $(\square)$ was assayed in the absence of Triton $\mathrm{X}-100$. LDH, lactate dehydrogenase; ALP, alkaline phosphatase.

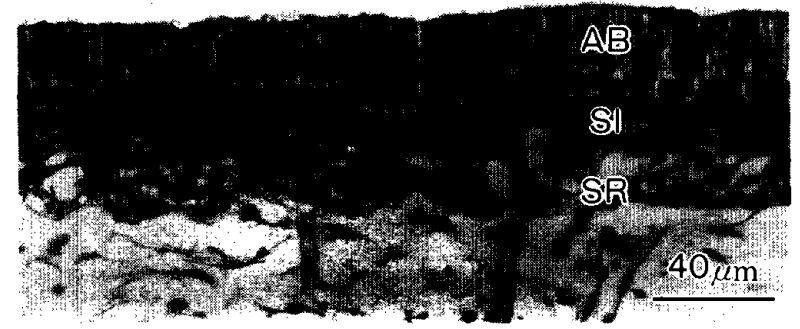

Fig. 7 Light micrograph showing a bovine enamel organ separated from the bovine tooth germs. Enamel organ consists of a single layer of ameloblasts (AB), stratum intermedium (SI) and stellate reticulum (SR).

エナメル器はその内表面に多くのエナメル芽細胞が一層 見られ，その直下に中間層細胞，星状細胞などが少数観 察された，骨芽細胞やセメント芽細胞のような石灰化能 を有する中肧葉性細胞は観察されなかった。このこと は, ウシ歯胚エナメル芽細胞層を採取する時に中胚葉組 織由来の細胞は混入していないことを示している. 
B，細胞外基質小胞画分における LDH を含む小胞の 存在

ウシ歯胚エナメル芽細胞層から調製した細胞外基質小

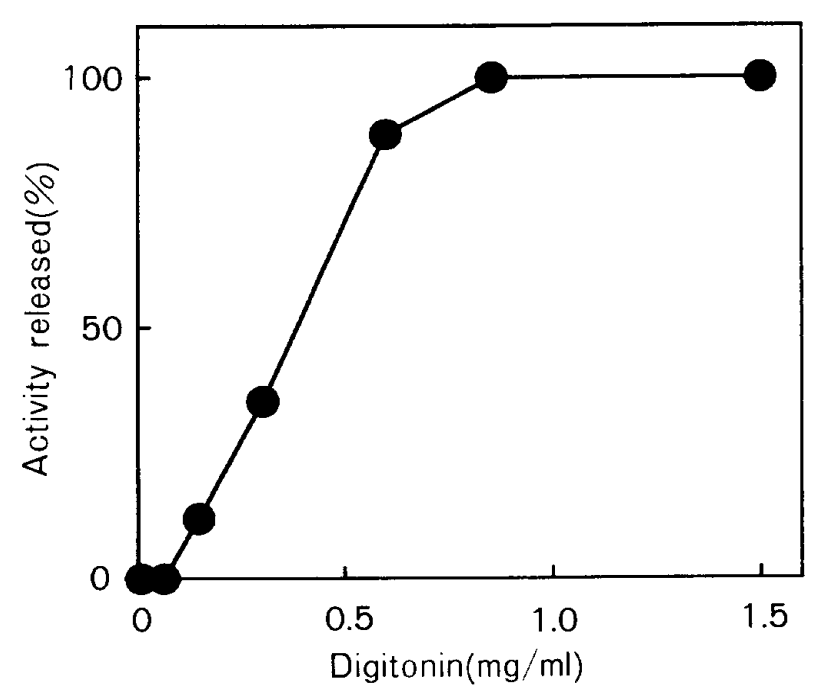

Fig. 8 Solubilization profile of lactate dehydrogenase from the extracellular matrix vesicle fraction from ameloblast layer of bovine tooth germs.

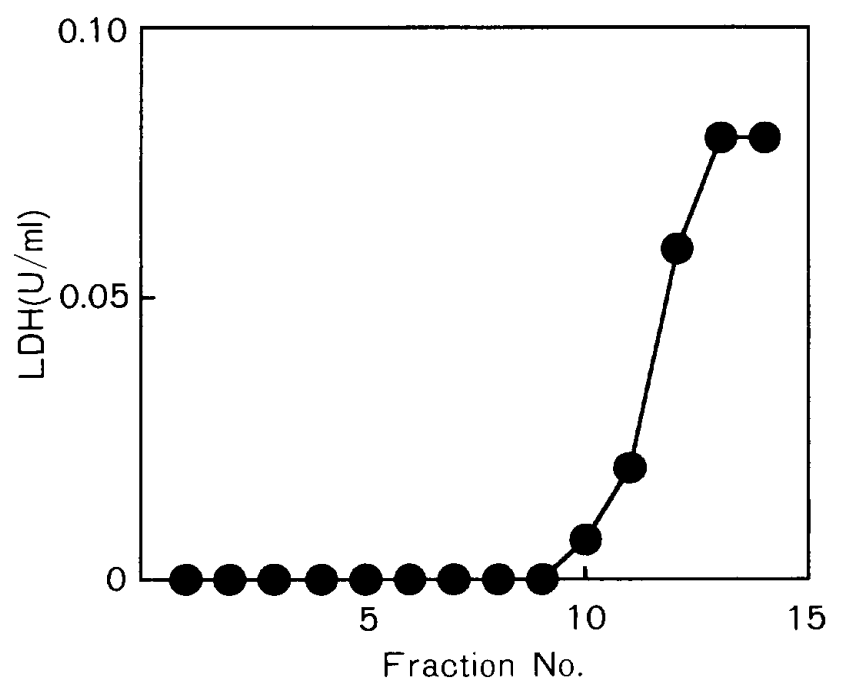

Fig. 9 Sucrose density gradient centrifugation of ameloblast homogenate. The ameloblast fraction prepared from bovine tooth germs was homogenized with 1.0 $\mathrm{ml}$ of $0.25 \mathrm{M}$ sucrose $/ 25 \mathrm{mM}$ Tris- $\mathrm{HCl}$ buffer, $\mathrm{pH} 7.5$, and subjected to sucrose density gradient centrifugation. $\mathrm{LDH}$ activity (O) was determined in the presence of Triton $\mathrm{X}-100 . \mathrm{LDH}$, lactate dehydrogenase.
胞画分の LDH 活性は象牙芽細胞層之同様, Triton X100 の非存在下では全く検出されず, digitonin の添加 に伴い可溶化が進行し, digitonin 濃度 0.5\%（v/v） で, 可溶化した LDH 活性は最大值に達した（Fig. 8). 以上の結果は LDH を含む小胞がウシ歯肧エナメル芽細 胞層の細胞外基質小胞画分中にも存在すること，また LDH が小胞のマトリックスに存在していることを示し ている.

C. $\mathrm{LDH}$ を含む小胞の由来

エナメル芽細胞ホモジネートの蔗糖密度勾配遠心分画 に执いて, Triton X-100の存在の有無に関わらず LDH 活性は可溶性画分（シトゾール画分）にのみ回収され， 沈降しなかった（Fig. 9). またエナメル芽細胞から超

A B

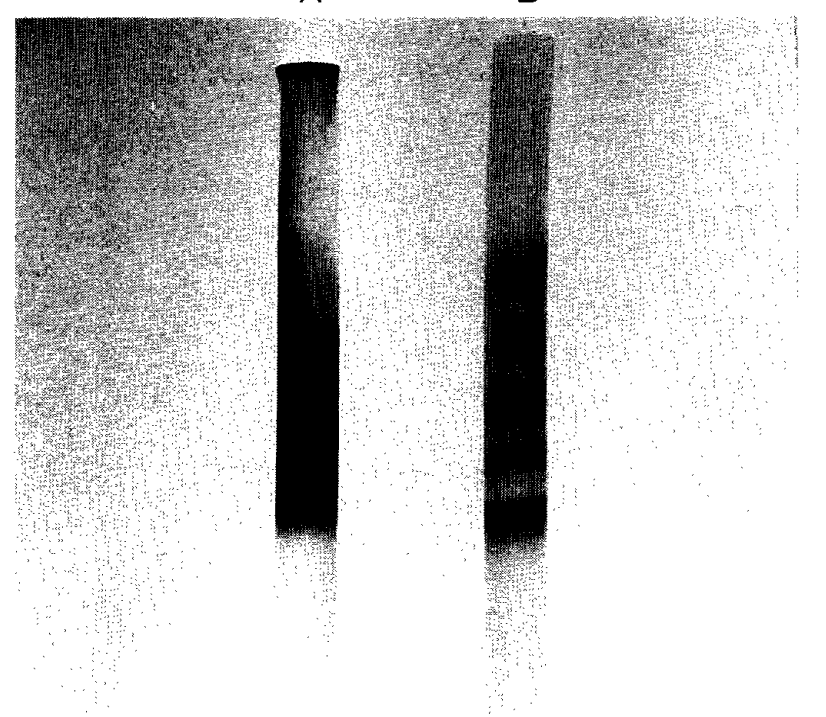

Fig. 10 Polyacrylamide gel electrophoresis of lactate dehydrogenase-containing vesicles and cytosolic lactate dehydrogenase isoenzymes. The cytosolic fractions of ameloblasts and LDH-containing vesicles were prepared from bovine tooth germs. LDH-containing vesicles were solubilaized with $0.2 \%$ Triton $\mathrm{X}-100$ and centrifuged at $100,000 \mathrm{~g}$ for $60 \mathrm{~min}$. LDH -containing vesicles and the cytosolic fraction of ameloblasts were separately subjected to polyacrylamide gel electrophoresis as described in the text. A, LDH-containing vesicles; $\mathrm{B}$, cytosol of ameloblasts. LDH, lactate dehydrogenase. 


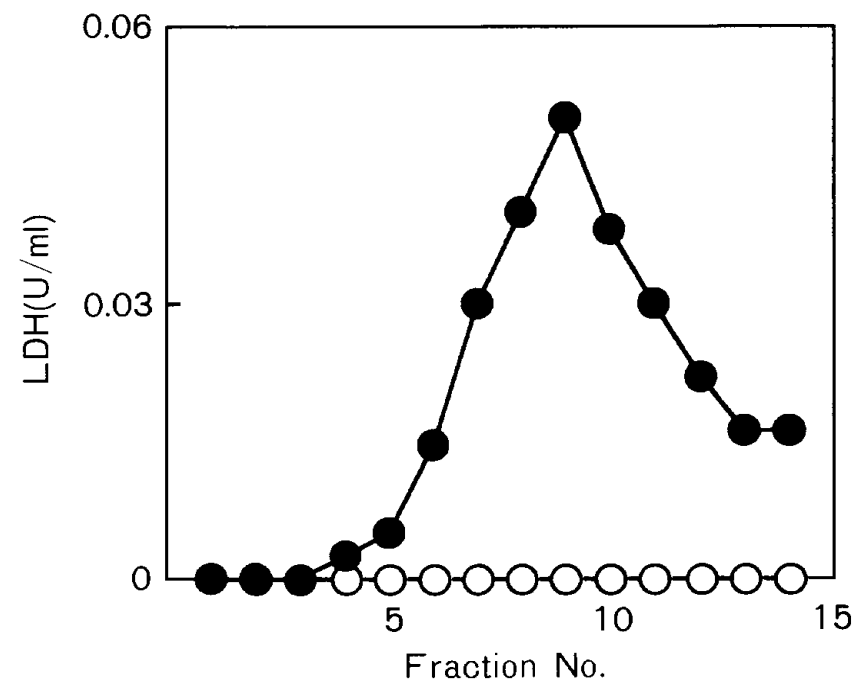

Fig. 11 Sucrose density gradient centrifugation of the extracellular matrix vesicle fraction from ameloblast layer of bovine tooth germs. Details of the procedures are described in the text. LDH activity was determined in the absence $(O)$ and the presence ( ) of Triton X-100. LDH, lactate dehydrogenase.

音波処理により人工的に調製した細胞外基質小胞画分で は, Triton X-100の存在下でェナメル芽細胞ホモジ ネートの LDH 活性の約 11\%の LDH 活性が検出され た.しかし Triton X-100の非存在下であほぼ同じ値の 活性が検出された。 以上の結果はエナメル芽細胞層の LDH を含む小胞は, 細胞形質膜や細胞内オルガネラ膜 に人工的に由来するものではないことを示している.

D. 小胞のLDH アイソェンザイムパターン

Fig. 10 にウシ歯胚エナメル芽細胞層の細胞外基質小 胞画分の抽出液上, エナメル芽細胞のシトゾール画分の ポリアクリルアミドゲル電気泳動によるLDH のアイソ エンザイムパターンを示す. 両画分の LDH の 5 個のア イソェンザイムパターンは非常に類似していた.

E． LDH を含む小胞の蔗糖密度勾配遠心法による精 製

ウシ歯胚エナメル芽細胞層から調製した細胞外基質小 胞画分を蔗糖密度勾配遠心分画により精製した（Fig. 11). Triton X-100の非存在下では LDH 活性は全く検 出されなかったが, Triton X-100を添加すると LDH 活性が出現した。

他方, エナメル芽細胞シトゾールに存在する LDH 以 外の酵素として aspartate：2-oxoglutarate aminotransferase, alanine : 2 -oxoglutarate aminotransf- erase, aldolase を測定したが，活性は検出されなかっ た。このことはウシ歯胚エナメル芽細胞層に LDH を特 異的に取り込む小胞が存在することを示している.

\section{考察}

石灰化組織には軟骨, 象牙質, セメント質などの中胚 葉性組織と, 上皮性石灰化を示すエナメル質とが存在す る. 現在, 上皮性石灰化を示すエナメル質以外の硬組織 での石灰化の開始は基質小胞によって行われるという説 が一般的に受け入れられている。 基質小胞は直径 $30-$ $300 \mathrm{~nm}$ の膜性小器官であり ${ }^{1,2)}$, その小胞膜には細胞形 質膜の醉素である ALP, 5 '-AMPase, pyrophosphatase などが存在し，特に ALP 活性が高いことが報告さ れている6,20). また，基質小胞膜のリン脂質の分布が細 胞形質膜と類似していることなどから，基質小胞は細胞 から発芽により形成され，石灰化前線に運ばれ，そこで 石灰化を開始すると考えられている211.

他方基質小胞は，動脈硬化症，骨肉腫，軟骨肉腫な ど22-24)の病的組織における異所性石灰化部位にも出現す ることが報告されている，保存修復処置における窩洞形 成時や露䯣後に形成される修復象牙質においても基質小 胞が観察されたという形態学的報告 ${ }^{25}$ がある.

しかしながら，時に細胞破片等が基質小胞様の構造物 として観察されること，また細胞質突起の縌断面が基質 小胞と間違って観察されるといった報告むある ${ }^{26.277}$.さ らに生化学的には, 基質小胞は小胞画分調製時に生じる 人工産物である可能性が指摘されている ${ }^{28)}$.

最近 Hosokawa ら $(1988)^{8)}$ および Takeuchi ら(1990 ) 9 ) は, 従来の生化学的方法を用いて基質小胞画分を調 製し, ラット肋軟骨骨端部の成長層にはALP と LDH の両活性を有する基質小胞が存在するのに対し, 静止首 には ALP を含まず LDH のみを含む基質小胞様小胞が 存在することを明らかにした。また内藤ら $(1991)^{10)}$ は ラット頭蓋骨膜性化骨部位を用いて基質小胞とは密度の 異なる $\mathrm{LDH}$ を含む基質小胞様小胞が存在することを明 らかにした。 しかし，これらの LDH を含む小胞の機能 は全く不明である.

本研究では，基質小胞性石灰化を行うとされているウ シ柬胚象牙芽細胞層と基質小胞の関与しない上皮性石灰 化を行うとされているエナメル芽細胞層を用いて, LDH を含む小胞の存在について検討を行った.

ウシ歯肧象牙芽細胞首の細胞外基質小胞画分を用いて LDH 活性を測定したところ, 界面活性剂の存在下での み $\mathrm{LDH}$ 活性が検出された。この結果は細胞外基質小胞 
画分における LDH を含む小胞の存在を示している。一 方, 細胞内オルガネラの蔗糖密度勾配遠心分画を行った ところ，LDH 活性はシトゾール画分にのみ検出され沈 降しなかった．また細胞形質膜や細胞内オルガネラを超 音波処理し人工的に小胞画分を調製し， LDH 活性を測 定したところ活性は検出されたが，その值は界面活性剤 の存在下でも非存在下でも変わらなかった。これらの結 果は, LDH を含む小胞は細胞形質膜や細胞内顆粒成分 に人工的に由来するあのではなく, in vivo で形成され た小胞であることを示している．さらにウシ歯胚象牙芽 細胞層の細胞外基質小胞画分の蔗糖密度勾配遠心分画を 行ったところ, 界面活性剤の存在下でのみ $\mathrm{LDH}$ 活性が 検出された。この LDH 活性は基質小胞のマーカーであ る ALP 活性とは沈降パターンが異なっていた，以上の 結果はウシ歯胚象牙芽細胞層には基質小胞とは異なる $\mathrm{LDH}$ を含む小胞が存在することを示している。この小 胞の LDH のアイソエンザイムパターンは細胞シトゾー ルのパターンと類似していた。 また細胞シトゾールに存 在する他の䣲素として aspartate：2-oxoglutarate aminotransferase, alanine: 2-oxoglutarate aminotransferase, aldolase を測定したが，いずれの活性

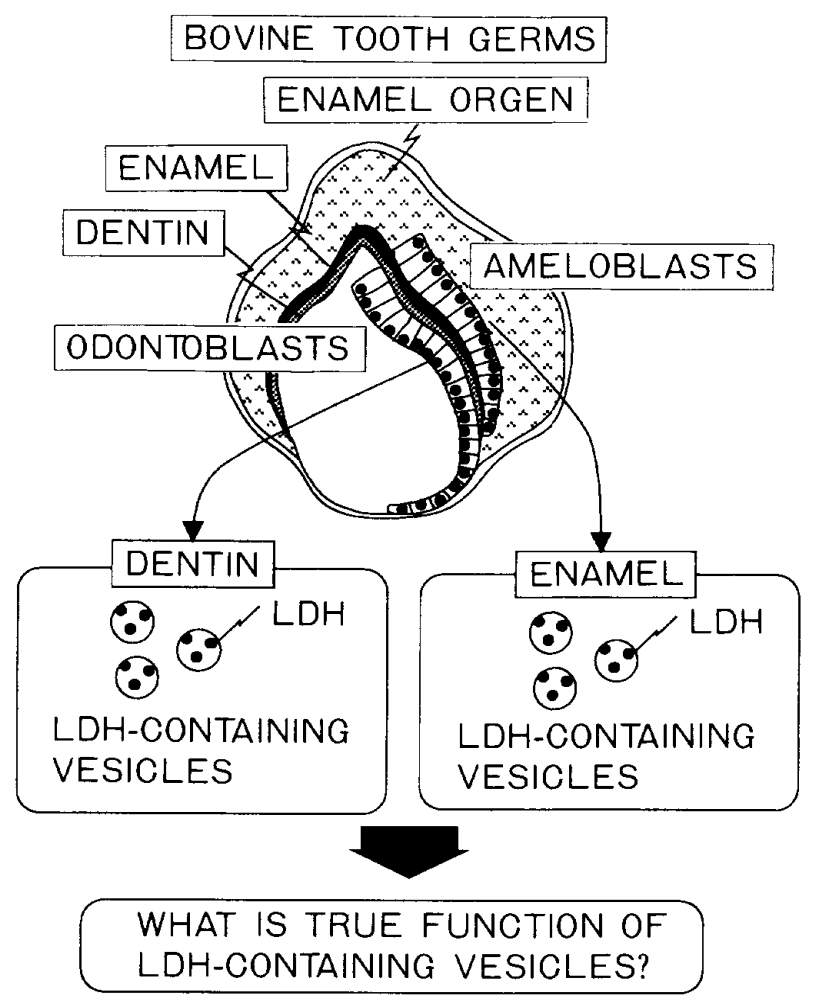

Fig. 12 The shema for the destribution of LDH containing vesicles of bovine tooth germs. LDH, lactate dehydrogenase.
あ小胞画分には検出されなかった。 これらのことは小胞 に LDH を特異的に取り込む機構が存在することを示し ている。

さらに，ウシ歯胚エナメル芽細胞層にす LDH を含む 小胞が存在することが同様の方法により示された。 LDH を含む小胞はこれまで，基質小胞が関与する軟骨 や骨の初期石灰化開始部位加ら調製した細胞外基質小胞 画分中に検出されてきた。 しかしながら今回の研究で, 基質小胞性石灰化を行う之されているウシ歯胚象牙芽細 胞層のみならず，基質小胞の関与しない上皮性石灰化を 行うとされているウシ㐘胚エナメル芽細胞首にも LDH を含む小胞が存在することが明らかにされた，従って LDH を含む小胞は基質小胞とは異なった機能を持っと 考えられる (Fig. 12).

基質小胞の機能に関する報告は数多くあるが，LDH を含む小胞の機能は不明である。この小胞の形成機構や 生理的意義は今後の重要な研究課題である.

\section{結論}

ウシ歯胚象牙芽細胞層およびエナメル芽細胞層の初期 石灰化開始部位から調製した細胞外基質小胞画分を䤃素 学的に検討し, 以下のような知見を得た。

1. ウシ歯胚象牙芽細胞層加ら調製した細胞外基質小 胞画分の LDH 活性は, 界面活性剂の存在下でのみ検出 された。このことは，LDH が細胞外基質小胞画分の小 胞のマトリックスに存在することを示している.

2. 分画遠心により得られたウシ歯胚象牙芽細胞画分 の LDH 細胞内分布を蔗糖密度勾配遠心により調べたよ ころ，LDH は細胞のシトゾールにのみ存在することが 明らかになった，以上の結果は，細胞外基質小胞画分の $\mathrm{LDH}$ 活性は細胞の形質膜や細胞内顆粒成分に由来する すのではないことを示している.

3. ウシ象牙芽細胞画分の超音波処理により人工的に 小胞画分を調製し，LDH 活性を測定したところ，界面

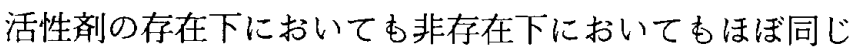
活性が検出された。このことから細胞形質膜や細胞内オ ルガネラ膜の破壊により人工的に形成される小胞では, LDH は小胞膜の外表面に付着していることが明らかに なった。これは，マトリックスに $\mathrm{LDH}$ を含む小胞は in vivoで形成されたことを示している.

4. ウシ歯胚象牙芽細胞シトゾールの LDH と細胞外 基質小胞画分の LDH のアイソエンザイムの電気泳動パ ターンは非常に類似していた。 また細胞外基質小胞画分 には，LDH 以外に細胞のシトゾールに存在する酵素は 
検出されなかった．これらの結果は LDH を小胞内に選 択的に取り込む機構が存在することを示唆する.

5。 ウシ歯胚象牙芽細胞層から調製した細胞外基質小 胞画分の蔗糖密度勾配遠心分画において，基質小胞の マーカーであるALP と界面活性郕存在下での LDH 活 性の沈降パターンは異なっていた，以上の結果は，ウシ 歯胚象牙芽細胞層の LDH を含む小胞は基質小胞とは異 なることを示している.

6．ウシ歯胚エナメル芽細胞層にも象牙芽細胞層と同 様，LDH を含む小胞が存在することが明らかになった。

7. 基質小胞の関与しない上皮性石灰化を行うエナメ ル質の初期石灰化部位に LDH を含む小胞が存在するこ とから，この小胞は基質小胞とは異なる機能を有するも のと考えられる。

稿を終えるに臨み，本研究に際し終始御親切なる御指 導および御校閲を睗わった九州歯科大学歯科保存学第 1 講座寺下正道教授，ならびに九州歯科大学生化学講座野 口知雄教授に心より感謝の意を表します。また，本研究 に多くの御助言, 御協力を頂いた九州歯科大学口腔解剖 学第 2 講座豊島邦昭助教授に心より御礼申し上げると之 あに，数々の御援助，御協力を頂いた生化学講座，歯科 保存学第 1 講座の諸先生方に厚く御礼申し上げます。

なお本研究の一部は，平成 4 年度科学研究費補助金 (特別研究員奖励費 27102 号, 学術振興会特別研究員 DC 2087）によった。

\section{文献}

1) Anderson, H. C. : Electron microscopic studies of induced cartilage development and calcification. J. Cell Biol. 35 : 81 - 101, 1967.

2 ) Bonucci, E. : Fine structure of early cartilage calcification. J. Ultrastruct. Res. 20:33-50, 1967.

3 ) Bernard, G. W. and Pease, D. C. : An electron microscopic study of initial intramembranous osteogenesis. Am. J. Anat. 125 : 271-290, 1969.

4) Bonucci, E.: The locus of initial calcification in cartilage and bone. Clin. Orthop. Relat. Res. $78: 108$ 139, 1971

5 ) Eisenmann, D. R. and Glick, P. L. : Ultrastructure of initial crystal formation in dentin. J. Ultrastruct. Res. $41: 18-28,1972$

6) Ali, S. Y., Sajdera, S. W. and Anderson, H. C. : Isolation and characterization of calcifying matrix vesicles from epiphyseal cartilage. Proc. Natl. Acad. Sci. U. S. A. $67: 1513-1520,1970$.
7 ) Wuthier, R. E. : Lipid composition of isolated epiphyseal cartilage cells, membranes and matrix vesicles. Biochim. Biophys. Acta 409:128-143, 1975.

8) Hosokawa, R., Uchida, Y., Fujiwara, S. and Noguchi, $\mathrm{T}$. : Lactate dehydrogenase isoenzymes are present in matrix vesicles. J. Biol. Chem. $263: 10045-10047$, 1988.

9) Ohashi-Takeuchi, H., Yamada, N., Hosokawa, R. and Noguchi, T.: Vesicles with lactate dehydrogenase and without alkaline phosphatase present in the resting zone of epiphyseal cartilage. Biochem. J. $266: 309-312,1990$.

10）内藤 徹：膜性化骨部位の Lactate dehydrogenase 含有 基質小胞様顆粒に関する研究。九州歯会誌 $46: 345-$ 354, 1992.

11) Bergmeyer, H. U. and Bernt, E. : Lactate dehydrogenase. UV-assay with pyruvate and NADH. In : Methods of enzymatic analysis (ed. by Bergmeyer, H. U.). 2 nd English ed. Academic Press, New York, 1974, $574-579$.

12) Bergmeyer, H. U., Gawehn, K. and Grassl, M. : Enzymes as biochemical reagents. In: Methods of enzymatic analysis (ed. by Bergmeyer, H. U.). 2 nd English ed. Academic Press, New York, 1974, $496-$ 497.

13) Bergmeyer, H. U., Gawehn, K. and Grassl, M. : Enzymes as biochemical reagents. Aldolase. In : Methods of enzymatic analysis (ed. by Bergmeyer, H. U.). 1 st English ed. Academic Press, New York, 1974, 727 -733 .

14) Bergmeyer, H. U. and Bernt, E. : Glutamate-oxaloacetatetransaminase. UV-assay, manual method. In : Methods of enzymatic analysis (ed. by Bergmeyer, H. U.). 2 nd English ed. Academic Press, New York, 1974, 727-733.

15) Bergmeyer, H. U. and Bernt, E. : Glutamate-pyruvate transaminase. UV-assay, manual method. In Methods of enzymatic analysis (ed. by Bergmeyer, H. U.). 2 nd English ed. Academic Press, New York, 1974, 752 -758 .

16) Wuthier, R. E., Linder, R. E., Warner, G. P., Gore, S. T. and Borg, T. K. : Non-enzymatic Isolation of Matrix Vesicles: Characterization and Initial Studies in ${ }^{45} \mathrm{Ca}$ and ${ }^{32} \mathrm{P}$-orthophosphate metabolism. Metab. Bone Dis. Related Res. 1 : $125-136,1978$.

17) Noguchi, T. and Fujiwara, S. : Developmental profiles and properties of hepatic peroxisomal apo- and mitochondrial holoalanine: glyoxylate aminotransferase during chick embryogenesis. J. Biol. Chem. $259: 14498-14504,1984$.

18) Fritz, P. J., Morrison, W. J., White, E. L. and Vesell, E. S. : Comparative study of methods for quantitation of lactate dehydrogenase isozymes. Anal. 
Biochem. 36:443-453, 1970.

19) Nitisewojo, P. and Hultin, H. O. : A comparison of some kinetic properties of soluble and bound lactate dehydrogenase isoenzymes at different temperatures. Eur. J. Biochem. $67: 87-94,1976$.

20) Watkins, E. L., Stillo, J. V. and Wuthier, R. E. : Subcellular fractionation of epiphyseal cartilage. Isolation of matrix vesicles and profiles of enzymes, phospholipids, calcium and phosphate. Biochim. Biophys. Acta $631: 289-304,1980$.

21) Wuthier, R. E. : Mechanism of matrix vesicle mediated mineralization of cartilage. ISI Atras Sci. : 231 $241,1988$.

22) Nilsen, R. : Electron-microscopic study of mineralization in induced heterotopic bone formation in guinea pig. Scand. J. Dent. Res. $88: 340-347,1980$.

23) Kim, K. M. and Huang, S. H. : Ultrastructural study of calcification of human aortic valve. Lab. Invest. $25: 357-366,1971$.

24) Kim, K. M. : Calcification of matrix vesicles in human aortic valve and aortic media. Fed. Proc. 35 : $156-162,1976$.

25) Sela, J., Tamari, I., Hirschfeld, Z. and Bab, I. : Transmission electron microscopy of reparative dentin in rat molar pulps. Primary mineralization via extracellular matrix vesicles. Acta Anat. 109:247 $-251,1981$.

26) Nelson, S. M. and Nora, L. S. : Electron microscopic evaluation of the occurrence of matrix vesicles in cartilage. Anat. Rec. $227: 397-404,1990$.

27) Landis, W. J., Paine, M. C., Hodgens, K. J. and Glimcher, M. J. : Matrix vesicles in embryonic chick bone : considerations of their identification, number, distribution, and possible effects on calcification of extracellular matrices. J. Ultrastruct. Mol. Struct. Res. 95: $142-163,1986$.

28) Boothroyd, B.: Observations on embryonic chick bone crystals by high resolution transmission electron microscopy. Clin. Orthop. Relat. Res. 106 : 290$310,1975$. 